\title{
Intrastromal crosslinking in post-LASIK ectasia
}

\author{
"Crosslinking" intraestromal em ectasia pós-LASIK
}

Bernardo Kaplan Moscovicl ${ }^{1}$, Mauro Campos $^{1}$

\begin{abstract}
We describe a case of early post-LASIK ectasia detected in the first 6 months after surgery. The patient was treated by means of intrastromal corneal crosslinking under the flap, without de-epithelialization, which resulted in a positive outcome. At the time of writing, 2 years after the procedure, the patient remained free of progression.
\end{abstract}

Keywords: Astigmatism; Refractive surgical procedures; Keratomileusis, laser in situ; Corneal wavefront aberrations; Cross-linking reagent; Corneal stroma; Postoperative complications; Humans; Female; Adult; Case reports

\section{RESUMO}

Descrevemos um caso de ectasia de córnea precoce após cirurgia de LASIK, detectado no primeiro semestre pós-operatório. Nós optamos tratareste paciente com "crosslinking" embaixo do "flap", sem desepitelização com bons resultados. A paciente permaneceu sem progressão da ectasia até o momento atual, dois anos após o procedimento.

Descritores: Astigmatismo; Procedimentos cirúrgicos refrativos; Ceratomileuse assistida por excimer laser in situ; Aberrações de frente de onda da córnea; Reagentes paraligações cruzadas; Substância própria; Complicações pós-operatórias; Humanos; Feminino; Adulto; Relatos de casos

\section{INTRODUCTION}

A 28-year-old female was referred to the Universidade Federal de São Paulo (UNIFESP), Department of Refractive Surgery in 2010 for refractive surgery. Her refraction was -3.25 D -0.75 D $160^{\circ}(\mathrm{OD})$ and $-3.25 \mathrm{D}-0.75 \mathrm{D} 180^{\circ}(\mathrm{OS})$. Corneal topography revealed an asymmetry of less than 0.5 diopters in the left eye (Figure 1). Corneal thickness of right eye was $590 \mu \mathrm{m}$ and the left eye was $591 \mu \mathrm{m}$. We performed wavefront-guided laser-assisted in situ keratomileusis (LASIK) surgery in both the eyes using a Moria M2 microkeratome and LADARVision excimer laser with an ablation depth of $63.8 \mu \mathrm{m}$ in the right eye and $70.5 \mu \mathrm{m}$ in the left eye. There were no immediate postoperative complications and the uncorrected visual acuity was 20/20 bilaterally.

Four months after the procedure, the patient returned with a complaint of decreased visual quality in the right eye. Visual acuity was 20/25 uncorrected and 20/20 with -0.25 D -0.50 D 15 lenses. A comparison of corneal topography findings between postoperative months 1 and 4 (Figure 2) showed inferior corneal steepening (>1 diopter) in the right eye and a diffuse increase in corneal curvature $(<1$ diopter) in the left eye. Corneal optical coherence tomography (OCT, Figure 3) showed an abnormally thick flap (200-220 $\mu \mathrm{m})$, whereas aberrometry showed a high RMS (0.84) and an increase in the negative vertical coma. As the patient was scheduled to leave the country within a week for her doctoral studies in Barcelona, we chose to perform under-the-flap intrastromal corneal crosslinking.

\section{Operative technique}

The flap was partially lifted with a corneal spatula so as to enable separation of the stroma above and under the flap, but without lifting the entire flap (Figure 4). A $0.1 \%$ riboflavin solution was injected into the stroma at 15-minute intervals for 30 minutes. Crosslinking was performed by standard technique by irradiating with $365 \mathrm{~nm}$ UV-A light of intensity $3.0 \mathrm{~mW} / \mathrm{cm}^{2}$.

Following surgery, the patient was prescribed with a 3-week course of low-dose corticosteroids (topical fluorometholone), a 1 -week course of a fourth-generation quinolone (topical gatifloxacin), and artificial tears for every 6 hours. Three days after the procedure, the uncorrected visual acuity in the treated eye was 20/25, with the typical corneal haze commonly observed in the early postoperative period of crosslinking in the flap area. The patient traveled as originally scheduled with instructions for eye care and under guidance to seek ophthalmologic evaluation in Barcelona.

\section{RESULTS}

The patient returned to our service for 1-year follow-up and was asymptomatic. The visual acuity was 20/20 in both eyes (OD: -0.75 D cyl $180^{\circ}$, OS: $-0.25 \mathrm{D} \mathrm{cyl} 140^{\circ}$ ), and corneal topography showed absence of disease progression bilaterally.

\section{DISCUSSION}

Post-LASIK corneal ectasia is a non-inflammatory process that results in deformation of the cornea along with thinning and biomechanical weakening ${ }^{(1-10)}$

Crosslinking is the gold-standard treatment for progressive corneal ectasia. However, it is often difficult to convince post-LASIK patients with early-stage ectasia to undergo this procedure because of slow and painful recovery periods ${ }^{(1-6)}$.

Some researchers have focused on preventing corneal de-epithelialization so as to achieve efficient and recovery from corneal

Submitted for publication: August 12, 2013 de São Paulo.

Department of Ophthalmology, Refractive Surgery Service, Universidade Federal de São Paulo (UNIFESP), São Paulo, SP, Brazil.

Funding: No specific financial support was available for this study.

Disclosure of potential conflicts of interest: None of the authors have any potential conflicts of interest to disclose.

Corresponding author: Bernardo Kaplan Moscovici. Rua Apiacás 600/84 - São Paulo - (SP) 05017-020 - Brazil - E-mail: bernardokaplan@yahoo.com.br 

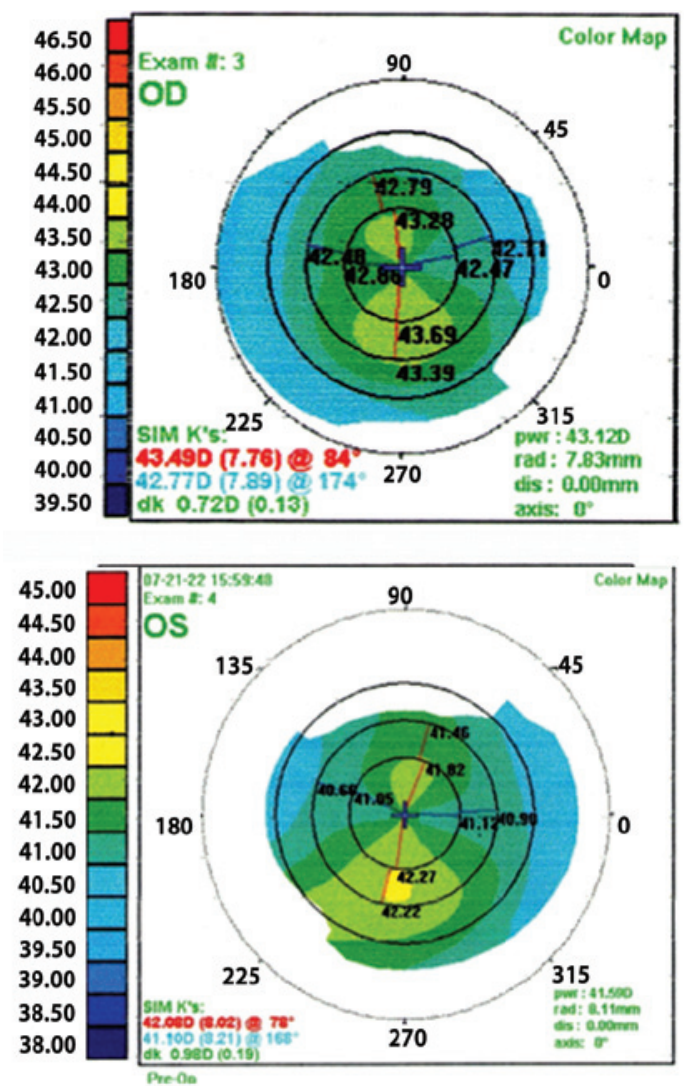

Figure 1. Preoperative corneal topography showing an asymmetry of less than 0.5 diopters in the left eye.

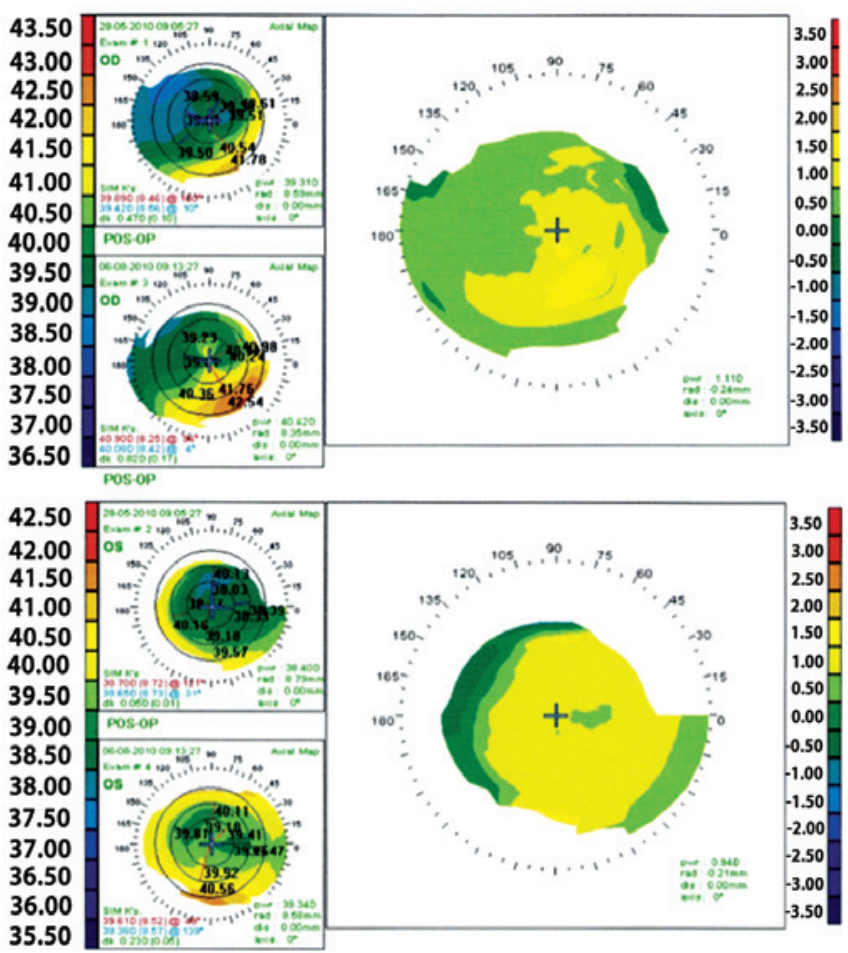

Figure 2. Differential corneal topography between first and fourth month postoperative, showing a steepening in both eyes, more evident in the right eye.

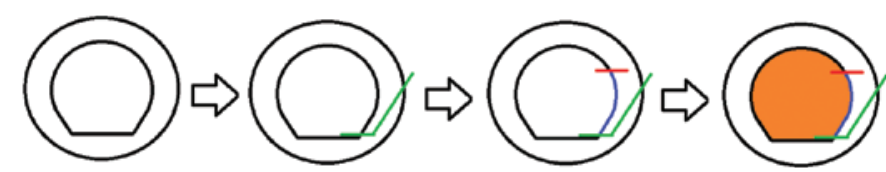

Figure 3. Postoperative optical coherence tomography of the cornea measuring the LASIK flap, showing an abnormally thick flap.

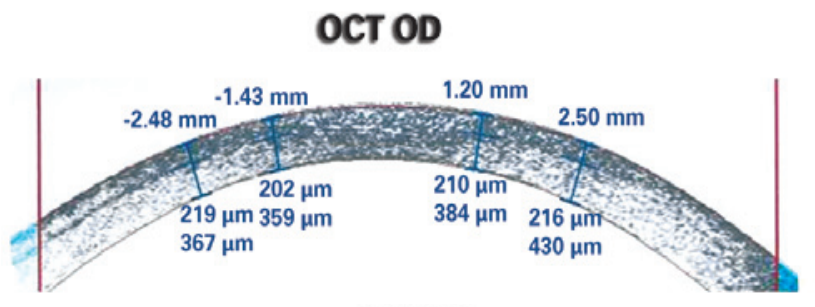

OCT OE

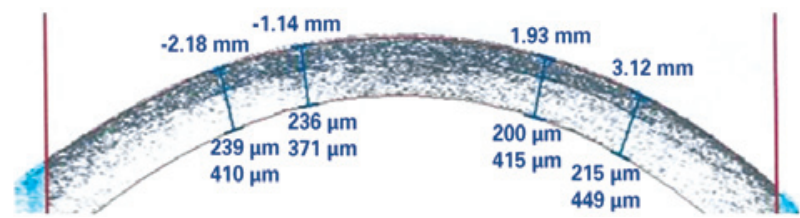

Figure 4. Illustration of the new technique: The flap was partially elevated with a corneal spatula to enable separation of the stroma above and under the flap, but without lifting the entire flap. A $0.1 \%$ riboflavin solution was injected into the stroma at 15 -minute intervals for 30 minutes and after the crosslinking was performed.

crosslinking. In one such study, femtosecond laser was used to create a pocket, and riboflavin was administered for only 2 minutes before UV-A irradiation ${ }^{(6)}$. We propose a new technique in which riboflavin is injected under the flap. As a preexisting flap is used, no decrease in biomechanical power of the cornea should occur. The only disadvantage of this technique over the usual procedure is the possibility of epithelial ingrowth, which can be easily avoided if the procedure is performed with care.

Double-blind, randomized, case-control studies are required to provide more reliable data, but this procedure appears simple, safe, and effective technique for management of post-LASIK ectasia.

\section{REFERENCES}

1. Brenner LF, Alió JL, Vega-Estrada A, Baviera J, Beltrán J, Cobo-Soriano R. Indications for intrastromal corneal ring segments in ectasia after laser in situ keratomileusis. J Cataract Refract Surg. 2012;38(12):2117-24.

2. Sakhtar S. Kirat O, Alkatan HT, Almubrad T. Stromal alteration in post-lasik ectasia córnea. Acta Ophthalmologica. 2012:90 Suppl.:S249.

3. Peinado TF, Pinero DP, López IA, Alió, JL. Correlation of both corneal surfaces in corneal ectasia after myopic LASIK. Optom Vis Sci. 2011;88(4):E539-42.

4. Gaster RN, Cnedo ALC, Rabinowits YS. Corneal collagen cross-linking for keratoconus and Post-LASIK ectasia. Int Ophthalmol Clin. 2013 Winter;53(1):79-90.

5. Kanellopoulos AJ, Collagen Cross-linking in Early Keratoconus with riboflavin in a femtosecond laser-created pocket: initial clinical results. J Refract Surg. 2009;25(11): 1034-7.

6. Randleman JB, Trattler WB, Stulting RD. Validation of the Ectasia Risk Score System for Preoperative Laser In Situ keratomileusis screening. Am J Ophthalmol. 2008;145(5): 813-8.

7. Spadea L, Cantera E, Cortes M, Conocchia NE, Stewart CW. Corneal ectasia after myopic laser in situ keratomileusis: a long-term study. Clin Ophthalmol. 2012;6:1801-13

8. Poli M, Cornut PL, Balmitgere T, Aptel F, Janin H, Burillon C. Prospective study of corneal collagen cross-linking efficacy and tolerance in the treatment of keratoconus and corneal ectasia: 3-year results. Cornea. 2013;32(5):583-90.

9. Coskunvensen E, Jankov MR 2nd, Hafezi F, Atun S, Arslan E, Kymionis GD. Effect of treatment sequence in combined intrastromal corneal rings and corneal collagen crosslinking for keratoconus. J Cataract Refract Surg. 2009;35(12):2084-91.

10. Kiliç A, Kamburoglu G, Akinci A. Riboflavin injection into the corneal channel for combined collagen crosslinking and intrastromal corneal ring segment implantation. J Cataract Refract Surg. 2012;38(5):878-83. Comment in: J Cataract Refract Surg. 2012; 38(10):1878-9; J Cataract Refract Surg. 2012;38(10):1879-80. 